\title{
Non-controlling interest in the consolidated financial statements of Dong Bac Corporation
}

\section{Thu Minh Thi Nguyen 1, ${ }^{*}$, Oanh Kim Hoang ${ }^{2}$}

1 Faculty of Economics and Business Administration, Hanoi University of Mining and Geology, Vietnam

2 Faculty of Accounting, Hanoi University of Business and Technology, Vietnam

\begin{tabular}{ll}
\hline ARTICLE INFO & ABSTRACT \\
\hline $\begin{array}{ll}\text { Article history: } \\
\text { Received 10th Aug. 2020 }\end{array}$ & $\begin{array}{l}\text { In the consolidated financial statements, the non-controlling interest is an } \\
\text { important indicator, a part of equity. The recognition of this criteria will }\end{array}$ \\
Revised 10th Sept. 2020 & $\begin{array}{l}\text { help the consolidated financial statements become more public, } \\
\text { transparent and accurate, and help shareholders to understand their }\end{array}$ \\
$\begin{array}{ll}\text { Keywords: } & \text { interestsin theinvestment process and in the capital contribution process. } \\
\text { Consolidated financial } & \text { However, at present, the regulations on recognition of non-controlling } \\
\text { statements, } & \text { interest are still controversial when corporations, parent companies, and } \\
\text { Dong Bac Corporation, } & \text { groups are implemented in practice, including Dong Bac Corporation. By } \\
\text { Joint stock company, } & \text { analyzing, synthesizing and evaluating methods, the author focuses on } \\
\text { Non-controlling interests. } & \text { researching the theoretical basis of non-controlling interest, clarifying } \\
& \text { how to recognize and present non-controlling interests at the Dong Bac } \\
& \text { Corporation. }\end{array}$
\end{tabular}

Copyright @ 2020 Hanoi University of Mining and Geology. All rights reserved.

${ }^{*}$ Corresponding author

E-mail: nguyenthu2012@gmail.com

DOI: 10.46326/JMES.KTQT2020.17 


\title{
Lợi ích cổ đông không kiểm soát trên báo cáo tài chính hợp nhất của Tổng công ty Đông Bắc
}

\author{
Nguyễn Thị Minh Thu 1, ${ }^{*}$, Hoàng Kim Oanh ${ }^{2}$ \\ 1 Khoa Kinh tế và Quản trị kinh doanh, Truoòng Đại học Mỏ - Địa chất, Việt Nam \\ ${ }^{2}$ Khoa Kế toán, Trường Đại học Kinh doanh và Công nghệ Hà Nội, Việt Nam
}

\section{THÔNG TIN BÅI BÁO $\quad$ TÓM TÁT}

Quá trình:

Nhận bài 10/8/ 2020

Sửa xong 10/9/2020

Chấp nhận đăng 31/ 10/ 2020

Tù khóa:

Báo cáo tài chính hợp nhất,

Công ty cổ phần,

Lợi ích cổ đông không

kiểm soát,

Tổng công ty Đông Bắc.
Trong báo cáo tài chính hợp nhất, chỉ tiêu Lợi ích của cổ đông không kiểm soát là một chỉ tiêu quan trọg, là một phần của vốn chủ sở hữu. Việc ghi nhận chỉ tiêu này sẽ giúp báo cáo tài chính hợp nhất công khai, minh bach và chính xác hơn, giúp các cổ đông hiểu rõ về lợi ích của minh trong quá trình đầu tư góp vốn. Tuy nhiên, hiện nay những quy định về ghi nhận lợi ích cổ đông không kiểm soát còn có nhiều tranh cãi khi các tống công ty, công ty mè, các tập đoàn triển khai trong thực tế, trong đó có Tổng công ty Đông Bắc. Bằng phương pháp phân tích, tổng hợp, đánh giá, tác giả tập trung nghiên cứu cơ sở lý luận về lợi ích cổ đông không kiểm soát, làm rõ cách thức ghi nhận và trình bày lợi ích cổ đông không kiểm soát tại Tổng công ty Đông Bắc.

(c) 2020 Trường Đại học Mỏ - Địa chất. Tất cả các quyền được bảo đảm.

\section{Mở đầu}

Trong các doanh nghiệp có hoạt động đầu tư vào công ty con hoặc hoạt động theo mô hình "công ty mẹ, công ty con", việc hợp nhất báo cáo tài chính là một công việc quan trọng, nhằm cung cấp thông tin một cách toàn diện cho các nhà đầu tư và các đối tượng quan tâm đến thông tin kế toán của các đơn vị này. Khi lập báo cáo tài chính hợp nhất, việc xác định chỉ tiêu Lợi ích của cổ đông không kiểm soát trên Bảng cân đối kế toán hợp nhất và Lợi nhuận sau thuế của cổ đông không kiểm soát trên Báo cáo kết quả kinh doanh được thực hiện như thế nào là một vấn đề cần được làm rõ.

\section{*Tác giả liên hệ}

E - mail: nguyenthu2012@gmail.com

DOI: 10.46326/ JMES.KTQT2020.17
Tổng công ty Đông Bắc là một doanh nghiệp trực thuộc Bộ Quốc Phòng có nhiệm vụ chính là sản xuất kinh doanh than và khoáng sản. Trong giai đoạn $2017 \div 2019$, Tổng công ty Đông Bắc thay đổi cơ cấu doanh nghiệp, do đó giữa các năm có sự thay đổi từ 02 đến 04 công ty cổ phần (CP) là công ty con. Các công ty CP thuộc Tổng công ty Đông Bắc được hình thành từ quá trình CP hóa các công ty con trực thuộc Tổng công ty Đông Bắc (thoái một phần vốn và bán $\mathrm{CP}$ ra ngoài cho các cổ đông không kiểm soát), không phải là quá trình thu mua công ty con. Do đó, trong khuôn khổ bài báo, tác giả chỉ trình bày việc tính toán và ghi nhận lợi ích cổ đông không kiểm soát trong báo cáo tài chính hợp nhất của Tổng công ty Đông Bắc trong giai đoạn $2017 \div 2019$. 


\section{Cơ sở lý luận về lợi ích cổ đông không kiểm soát}

\subsection{Khái niệm}

Theo thông tư 202/2014/TT-BTC, "Cổ đông không kiểm soát là cổ đông không có quyền kiểm soát công ty con (trước đây gọi là cổ đông thiểu số)" (Bộ Tài chính, 2014).

Theo Từ điển kinh tế học (Nguyễn Văn Ngọc, 2006), "lợi ích thiểu số là phần CP do công ty chi nhánh hoặc công ty con phát hành, nhưng không thuộc sở hữu của công ty mẹ. Nếu công ty mẹ sở hữu trên $50 \%$ CP của công ty chi nhánh, nó có thể kiểm soát công ty đó. Nhưng nếu phần sở hữu của nó dưới 50\%, người ta phải thừa nhận lợi ích của thiểu số các cổ đông khác".

Theo Chuẩn mực kế toán (VAS) 25 "Lơi ích của Cổ đông thiểu số (nay gọi là cổ đông không kiểm soát) là một phần của kết quả hoạt động thuần và giá trị tài sản thuần của một công ty con được xác định tương ứng cho các phần lợi ích không phải do công ty mẹ sở hữu một cách trực tiếp hoặc gián tiếp thông qua các công ty con" (Bộ Tài chính, 2015).

Như vậy, lợi ích cổ đông không kiểm soát là phần lợi ích không thuộc về công ty mẹ, mà thuộc về các cổ đông không nắm giữ quyền kiểm soát công ty con. Lợi ích của cổ đông không kiểm soát là một khoản mục trong báo cáo tài chính hợp nhất của công ty mẹ, thể hiện một tỷ lệ nắm giữ của cổ đông không kiểm soát đối với các công ty con của nó.

\subsection{Cách thức ghi nhận}

Chuẩn mực báo cáo tài chính quốc tế (IFRS) 10 quy định lợi ích cổ đông không kiểm soát được trình bày thành một chỉ tiêu riêng nằm trong vốn chủ sở hữu (IFRSs, 2014), trong khi VAS 25 yêu cầu trình bày lợi ích cổ đông không kiểm soát nằm ngoài phần vốn chủ sở hữu (Bộ Tài chính, 2015). Về bản chất, cổ đông không kiểm soát vẫn là cổ đông của công ty con và cổ đông của tập đoàn nên toàn bộ phần sở hữu của cổ đông cần phải được trình bày là một khoản mục thuộc vốn chủ sở hữu. Theo đó, quy định của VAS 25 là chưa phù hợp với bản chất và thông lệ quốc tế hiện hành.

Theo Thông tư 202/2014/TT-BTC, Lơi ích của Cổ đông không kiểm soát được ghi nhận trong quá trình lập báo cáo tài chính hợp nhất giữa công ty me và (các) công ty con. Trong đó, "Lơi ích cổ đông không kiểm soát được trình bày trong Bảng cân đối kế toán hợp nhất thành một chỉ tiêu riêng thuộc phần vốn chủ sở hữu. Phần sở hữu của cổ đông không kiểm soát trong Báo cáo kết quả kinh doanh của tập đoàn cũng phải được trình bày thành chỉ tiêu riêng biệt trong Báo cáo kết quả hoạt động kinh doanh hợp nhất" (Bộ Tài chính, 2014).

Lợi ích của cổ đông không kiểm soát trong tài sản thuần bao gồm 2 trường hợp:

- Giá trị các lợi ích của cổ đông không kiểm soát tại ngày hợp nhất kinh doanh ban đầu được xác định phù hợp với VAS11: "Hợp nhất kinh doanh".

- Phần lợi ích của cổ đông không kiểm soát trong sự biến động của tổng vốn chủ sở hữu kể từ ngày hợp nhất kinh doanh.

Trong trường hợp thứ nhất, lợi ích của cổ đông không kiểm soát tại công ty con được xác định tại thời điểm công ty mẹ tiến hành mua lại hoặc sáp nhập với một công ty con (hoặc nắm quyền kiểm soát công ty con này dưới hình thức gián tiếp, thông qua một công ty con trung gian khác), sau đó khoản mục lợi ích của các cổ đông không kiểm soát trong công ty con sẽ được xác định và trình bày lại trên báo cáo tài chính sau khi đã hợp nhất của công ty mẹ căn cứ vào chênh lệch giữa giá trị tài sản thuần và giá trị của khoản đầu tư.

Trường hợp thứ hai, phần lợi ích của cổ đông không kiểm soát được xác định tại thời điểm lập báo cáo tài chính hợp nhất của công ty mẹ cho thời gian hoạt động sau thời điểm kết thúc quá trình đầu tư của công ty me vào công ty con. Khi đó, các biến động của tài sản thuần và nguồn vốn chủ sở hữu trong thời gian hoạt động của công ty con sẽ được tính toán lại và phân bổ lại vào khoản mục "Lợi ích của cổ đông không kiểm soát" trên báo cáo tài chính hợp nhất của công ty mẹ (Bộ Tài chính, 2014).

Theo VAS 25, khoản lỗ vượt quá phần sở hữu của cổ đông không kiểm soát trong giá trị thuần của công ty con được tính cho cổ đông công ty mẹ, có nghĩa là lợi ích cổ đông không kiểm soát trên Bảng cân đối kế toán hợp nhất luôn không âm, trừ khi cổ đông này chấp nhận gánh chịu cho cổ đông me (Bô Tài chính, 2015). Tuy nhiên, bản chất lợ ích của cổ đông không kiểm soát là một khoản mục thuộc vốn chủ sở hữu, như vậy tất cả cổ đông đều được hưởng lợi ích cũng như phải gánh chịu phần lỗ tương ứng với phần sở hữu của mình mà không 
phân biệt cổ đông kiểm soát hay không kiểm soát nên quy định như VAS 25 là không phù hợp.

Theo Thông tư 202/2014/TT-BTC, Các khoản lỗ phát sinh tại công ty con phải được phân bổ tương ứng với phần sở hữu của cổ đông không kiểm soát, kể cả trường hợp số lỗ đó lớn hơn phần sở hữu của cổ đông không kiểm soát trong tài sản thuần của công ty con (Bộ Tài chính, 2014).

\subsection{Tách lọi ích của cổ đông không kiểm soát}

2.3.1. Nguyên tắc tách lọi ích của cổ đông không kiểm soát

Theo Thông tư 202/2014/TT-BTC, trong Bảng cân đối kế toán hợp nhất, lợi ích của cổ đông không kiểm soát trong giá trị tài sản thuần của các Công ty con được xác định và trình bày thành một dòng riêng biệt. Giá trị lợi ích của cổ đông không kiểm soát trong giá trị tài sản thuần của các Công ty con hợp nhất, gồm:

+Giá trị các lợiích của cổ đông không kiểm soát tại ngày mua được xác định phù hợp với VAS 11 "Hợp nhất kinh doanh";

+Lợi ích của cổ đông không kiểm soát trong sự biến động của tổng vốn chủ sở hữu kể từ ngày mua đến đầu năm báo cáo;

+Lợi ích của cổ đông không kiểm soát trong sự biến động của tổng vốn chủ sở hữu phát sinh trong năm báo cáo.

Các khoản lỗ tương ứng với phần sở hữu của Cổ đông không kiểm soát trong Công ty con được hợp nhất có thể lớn hơn số vốn của họ trong Công ty con. Khoản lỗ vượt trên phần vốn của các cổ đông không kiểm soát này được tính giảm vào phần lợi ích của Công ty mẹ trừ khi cổ đông không kiểm soát có nghĩa vụ ràng buộc và có khả năng bù đắp các khoản lỗ đó. Nếu sau đó Công ty con có lãi, khoản lãi đó sẽ được phân bổ vào phần lợi ích của Công ty mẹ cho tới khi phần lỗ trước đây do Công ty mẹ gánh chịu được bồi hoàn đầy đủ.

Trên Báo cáo kết quả hoạt động kinh doanh hợp nhất, lợi ích của cổ đông không kiểm soát được xác định và trình bày riêng biệt trong mục "Lợi nhuận sau thuế của cổ đông không kiểm soát". Lợi ích của cổ đông không kiểm soát được xác định căn cứ vào tỷ lệ lợi ích của cổ đông không kiểm soát và lợi nhuận sau thuế thu nhập doanh nghiệp của các Công ty con.

Lợi ích của cổ đông không kiểm soát trong tài sản thuần của Công ty con hợp nhất trên Bảng cân đối kế toán hợp nhất được trình bày ở mục C thuộc phần Nguồn vốn “C- Lợi ích của cổ đông không kiểm soát - Mã số 439".

Thu nhập của cổ đông không kiểm soát trong kết quả hoạt động kinh doanh của Công ty con được phản ánh trong mục "Lợi nhuận sau thuếcủa cổ đông không kiểm soát - Mã số 62" (Bộ Tài chính, 2014).

2.3.2. Kếtoán lợi ích của cổ đông không kiểm soát

Theo Thông tư 202/2014/TT-BTC, có 2 phương pháp kế toán lợi ích cổ đông không kiểm soát (Bộ Tài chính, 2014).

a. Phương pháp 1

$$
\begin{array}{ccc}
\text { Lơi ích cổ } & \text { Lọi ích cổ } & \begin{array}{c}
\text { Lơi ích cổ đông } \\
\text { đông không } \\
\text { kiểm soát }
\end{array} \\
\text { cuôi kỳ } & \begin{array}{c}
\text { đông không } \\
\text { kiểm soát }
\end{array} & \begin{array}{c}
\text { khồn kiềm kỳ } \\
\text { soát phát sinh }
\end{array} \\
\text { trong kỳ }
\end{array}
$$

Để tách riêng giá trị khoản mục "Lợi ích của cổ đông không kiểm soát" trong tài sản thuần của Công ty con trên Bảng cân đối kế toán hợp nhất phải điều chỉnh giảm các khoản mục thuộc vốn chủ sở hữu như "Vốn đầu tư của chủ sở hữu", "Quỹ dự phòng tài chính", "Quỹ đầu tư phát triển", "Lợi nhuận sau thuế chưa phân phối",... và điều chỉnh tăng khoản mục "Lợi ích của cổ đông không kiểm soát" trên Bảng cân đối kế toán hợp nhất.

i) Tách lợi ích của cổ đông không kiểm soát tại ngày đầu kỳ báo cáo.

Căn cứ vào lợi ích của cổ đông không kiểm soát đã được xác định tại ngày đầu kỳ báo cáo kế toán ghi:

Nợ Vốn đầu tư của chủ sở hữu

Nợ Thặng dư vốn CP (CP)

Nợ Quỹ dự phòng tài chính

Nợ Quỹ đầu tư phát triển

Nợ Lợi nhuận sau thuế chưa phân phối

Nợ Các quỹ khác thuộc vốn chủ sở hữu

Nợ Chênh lệch đánh giá lại tài sản

Nợ Chênh lệch tỷ giá hối đoái

Có Lợi ích của cổ đông không kiểm soát.

Trường hợp giá trị các khoản mục thuộc vốn chủ sở hữu của Công ty con tại ngày đầu kỳ là số âm thì kế toán ghi Có các khoản mục đó thay vì ghi Nợ vào các khoản mục đó như trong bút toán trên.

ii) Ghi nhận lợi ích của cổ đông không kiểm soát từ kết quả hoạt động kinh doanh trong kỳ.

- Trường hợp kết quả hoạt động kinh doanh trong năm có lãi, kế toán xác định lợi ích của cổ 
đông không kiểm soát trong thu nhập sau thuế của các Công ty con phát sinh trong kỳ, ghi:

Nợ Lợi nhuận sau thuếcủa cổ đông không kiểm soát

Có Lợi ích của cổ đông không kiểm soát.

- Trường hợp kết quả hoạt động kinh doanh trong năm lỗ, kế toán xác định số lỗ các cổ đông không kiểm soát phải gánh chịu trong tổng số lỗ của các công ty con phát sinh trong kỳ, ghi:

Nợ Lợi ích của cổ đông không kiểm soát.

Có Lợi nhuận sau thuế của cổ đông không kiểm soát.

- Trường hợp trong kỳ đơn vị trích lập các quỹ đầu tư phát triển và quỹ dự phòng tài chính từ lợi nhuận sau thuế chưa phân phối, kế toán ghi:

Nợ Quỹ đầu tư phát triển

Nợ Quỹ dự phòng tài chính

Có Lợi nhuận sau thuế chưa phân phối.

- Trường hợp trong năm đơn vị phân phối lợi nhuận và trả cổ tức cho các cổ đông không kiểm soát, kế toán căn cứ vào số phân chia cho các cổ đông không kiểm soát ghi:

Nợ Lợi ích của cổ đông không kiểm soát

Có Lợi nhuận sau thuế chưa phân phối.

b. Phương pháp 2

Áp dụng trong trường hợp trong kỳ không có các giao dịch theo chiều ngược (công ty con không phải là bên bán) và công ty con không thu được các khoản cổ tức từ các đơn vị trong nội bộ tập đoàn.

Giá trị phần lợi ích cổ đông không kiểm soát cuối kỳ trong giá trị ghi sổ của tài sản thuần của công ty con (ngoài phần sở hữu trong chênh lệch giữa giá trị hợp lý và giá trị ghi sổ của tài sản thuần tại ngày mua) được xác định theo công thức sau:

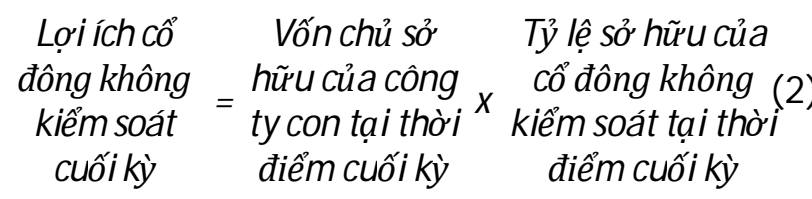

Do lợi ích cổ đông không kiểm soát cuối kỳ được tách từ vốn chủ của công ty con cuối kỳ nên các bút toán điều chỉnh khi công ty con trích lập các quỹ và trả cổ tức cho cổ đông không kiểm soát không được tiếp tục thực hiện.

Để tách riêng giá trị khoản mục "Lợi ích cổ đông không kiểm soát" trong tài sản thuần của công ty con trên Bảng cân đối kế toán hợp nhất phải điều chỉnh giảm các khoản mục thuộc vốn chủ sở hữu như "Vốn đầu tư của chủ sở hữu”, "Quỹ đầu tư phát triển”, "Lợi nhuận sau thuế chưa phân phối",... và điều chỉnh tăng khoản mục "Lợi ích cổ đông không kiểm soát” trên Bảng cân đối kế toán hợp nhất.

Căn cứ vào báo cáo tài chính riêng của từng công ty con cuối kỳ, kế toán tách lợi ích cổ đông không kiểm soát tại thời điểm cuối kỳ báo cáo, ghi:

Nợ Vốn góp của chủ sở hữu

Nợ Thặng dư vốn CP

Nợ Lợi nhuận sau thuế chưa phân phối

Nợ Quỹ khác thuộc vốn chủ sở hữu

Nợ Chênh lệch đánh giá lại tài sản

Nợ Chênh lệch tỷ giá hối đoái.

....

\section{Có Lợi ích cổ đông không kiểm soát.}

Trường hợp giá trị các khoản mục thuộc vốn chủ sở hữu của công ty con tại ngày đầu kỳ là số âm thì kế toán ghi Có các khoản mục đó thay vì ghi Nợ vào các khoản mục đó như trong bút toán trên.

\section{Thực trạng xác định và ghi nhận lợi ích cổ đông không kiểm soát cho các công ty CP thuộc Tổng công ty Đông Bắc giai đoạn 2017-2019}

Tổng công ty Đông Bắc là một doanh nghiệp có quy mô lớn với 17 đơn vị thành viên (bao gồm các đơn vị hạch toán phụ thuộc, công ty TNHHvà công ty cổ phần). Giai đoạn 2017-2019, Tổng Công ty Đông Bắc có sự thay đổi về cơ cấu doanh nghiệp, số lượng các công ty $\mathrm{CP}$ thay đổi liên tục. Năm 2017, chỉ có 2 công ty CP là Công ty CP than Sông Hồng và công ty $\mathrm{CP}$ Khoáng sản Miền Bắc. Năm 2018, số lượng công ty CP là 4, bao gồm công ty CP than Sông Hồng, công ty CP Khoáng sản Miền Bắc, công ty CPVận tải và Chế biến than Đông Bắc, công ty CP 397. Đến năm 2019, số lượng công ty CP còn lại là 3, bao gồm công ty $\mathrm{CP}$ than Sông Hồng, công ty CP Vận tải và Chế biến than Đông Bắc, công ty CP 397. Có sự thay đổi liên tục như vậy là do Tổng công ty Đông Bắc đang trong giai đoạn tái cơ cấu doanh nghiệp. Đây cũng là nguyên nhân của việc khi hợp nhất báo cáo tài chính, chỉ tiêu Lợi ích cổ đông không kiểm soát và Lợi nhuận sau thuế của cổ đông không kiểm soát có sự biến động liên tục.

\subsection{Cách thức ghi nhận lọi ích cổ đông không kiểm soát cho các công ty CP thuộc Tổng công ty Đông Bắc}

Tổng công Tổng công ty Đông Bắc ghi nhận lợi ích cổ đông không kiểm soát trên Báo cáo tài chính 
hợp nhất theo quy định của Thông tư 202/ 2014/ TT-BTCban hành ngày 22/ 12/ 2014.

Lợi ích của cổ đông không kiểm soát được ghi nhận trong quá trình lập báo cáo tài chính hợp nhất giữa công ty mẹ (Tổng công ty Đông Bắc) và các công ty con. Trong đó, lợi ích của cổ đông không kiểm soát trong tài sản thuần của công ty CP được xác định và trình bày trên bảng cân đối kế toán hợp nhất thành một chỉ tiêu riêng biệt, tách khỏi phần nợ phải trả và phần vốn chủ sở hữu của Cổ đông của công ty mẹ.

Các công ty CP thuộc Tổng công ty Đông Bắc được hình thành tù̀ quá trình $\mathrm{CP}$ hóa các công ty con trực thuộc Tổng công ty Đông Bắc (thoái một phần vốn và bán $\mathrm{CP}$ ra ngoài cho các cổ đông không kiểm soát), không phải là quá trình thu mua công ty con. Do đó, khoản mục lợi ích của các cổ đông không kiểm soát trong công ty con sẽ được xác định và trình bày lại trên báo cáo tài chính hợp nhất dựa theo tỷ lệ nắm giữ vốn của các cổ đông không kiểm soát sau khi Tổng công ty Đông Bắc bán xong CP ra ngoài, và được xác định tại ngày lập báo cáo tài chính hợp nhất đầu tiên (báo cáo tài chính hợp nhất của quý đầu tiên) sau khi CP hóa.

Phần lợi ích của cổ đông không kiểm soát được xác định tại thời điểm lập báo cáo tài chính hợp nhất của công ty me cho thời gian hoạt động sau thời điểm $\mathrm{CP}$ hóa, các biến động của tài sản thuần và nguî̀n vốn chủ sở hữu trong thời gian hoạt động của công ty con sẽ được tính toán và phân bổ lại vào khoản mục "Lợi ích của cổ đông không kiểm soát" trên Bảng cân đối kế toán hợp nhất và Thuyết minh báo cáo tài chính hợp nhất (Bảng 1, 2 ,3). Thu nhập sau thuế cũng được tính toán và phân bổ lại cho cổ đông không kiểm soát vào khoản mục "Lợi nhuận sau thuế của cổ đông không kiểm soát” trên Báo cáo kết quả hoạt động kinh doanh hợp nhất (Bảng 8).

\subsection{Tách lọi ích của cổ đông không kiểm soát tại Tổng Công ty Đông Bắc giai đoạn 2017- 2019}

Tổng công Tổng công ty Đông Bắc tách lợi ích Cổ đông không kiểm soát trên Báo cáo tài chính hợp nhất theo quy định của Thông tư 202/ 2014/ TT-BTCban hành ngày 22/ 12/ 2014.

3.2.1. Xác định chỉ tiêu Lợi ích cổ đông không kiểm soát trên Bảng cân đôi kế toán hợp nhất của Tổng công ty Đông Bắc
Do trong kỳ không có các giao dịch theo chiều ngược (công ty con không phải là bên bán) và công ty con không thu được các khoản cổ tức tù các đơn vị trong nội bộ tổng công ty Đông Bắc, nên giá trị phần lợi ích cổ đông không kiểm soát cuối kỳ được tính theo cách thức thứ 2. Cụ thể theo công thức(2).

Việc tính lợi ích cổ đông không kiểm soát cuối kỳ theo công thức (2) được thực hiện thông qua số liệu ở Bảng 4, 5, 6 .

Ví dụ: Ở Bảng 5, Tổng lợi ích của cổ đông không kiểm soát trong mỗi công ty CP thuộc Tổng công ty Đông Bắc cuối năm 2019 được tính như sau:

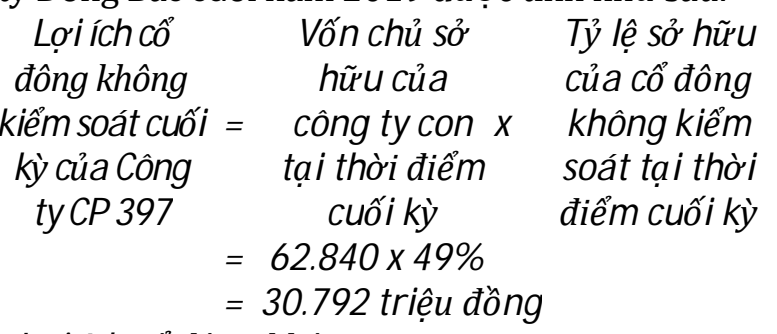

Lợi ích cổ đông không

kiểm soát cuôi kỳ của

Công ty CP Vận tải và

$=97.444 \times 49 \%$

Chế biến than Đông Bắc

= 47.748 triệu đồng

Lợi ích cổ đông không

kiềm soát cuôi kỳ của Công $=72.088 \quad$ x $\quad 45,38 \%$ ty CP than sông Hồng

$$
\text { = } 32.713 \text { triệu đồng }
$$

Như vậy Tổng lợi ích của cổ đông không kiểm soát cuối năm 2019 của Tổng công ty Đông Bắc là: $30.792+47.748+32.713=111.253$ triệu đồng.

Trong Bảng 1, 3, 5, số liệu được tính chi tiết cho từng khoản mục riêng lẻ trong Mục Vốn chủ sở hưu của Bảng cân đối kế toán.

Để tách riêng giá trị khoản mục "Lợi ích cổ đông không kiểm soát" trong tài sản thuần của công ty con trên Bảng cân đối kế toán hợp nhất phải điều chỉnh giảm các khoản mục thuộc vốn chủ sở hữu như "Vốn đầu tư của chủ sở hữu”, "Quỹ đầu tư phát triển", "Lợi nhuận sau thuế chưa phân phối",... và điều chỉnh tăng khoản mục "Lợi ích cổ đông không kiểm soát” trên Bảng cân đối kế toán hợp nhất.

Căn cứ vào báo cáo tài chính riêng của từng công ty con cuối kỳ, kế toán tách lợi ích cổ đông không kiểm soát tại thời điểm cuối kỳ báo cáo, ghi:

Nợ Vốn góp của chủ sở hữu

Nợ Quỹ đầu tư phát triển

Nợ Lợi nhuận sau thuế chưa phân phối Có Lợi ích cổ đông không kiểm soát. 
Bảng 1. Bảng tính lợi ích của cổ đông không kiểm soát của các công ty CP thuộc Tổng công ty Đông Bắc năm 2017.

\begin{tabular}{|c|c|c|c|c|c|c|c|}
\hline \multirow[b]{2}{*}{ Nội dung } & \multicolumn{3}{|c|}{ Công ty CP than Sông Hồng } & \multicolumn{3}{|c|}{$\begin{array}{l}\text { Công ty CP Khoáng sản } \\
\text { Miền Bắc }\end{array}$} & \multirow{2}{*}{$\begin{array}{l}\text { Tổng lợi } \\
\text { ích của } \\
\text { Cổ đông } \\
\text { không } \\
\text { kiểm }\end{array}$} \\
\hline & $\begin{array}{l}\text { Tổng } \\
\text { số }\end{array}$ & $\begin{array}{c}\text { Tổng } \\
\text { Công ty } \\
\text { Đông Bắc }\end{array}$ & $\begin{array}{c}\text { Cổ } \\
\text { đông } \\
\text { khác }\end{array}$ & $\begin{array}{l}\text { Tổng } \\
\text { số }\end{array}$ & $\begin{array}{c}\text { Tổng } \\
\text { Công ty } \\
\text { Đông Bắc }\end{array}$ & $\begin{array}{c}\text { Cổ } \\
\text { đông } \\
\text { khác }\end{array}$ & \\
\hline Tỷlê nắm giũu & $100 \%$ & $54,62 \%$ & $45,38 \%$ & $100 \%$ & $86 \%$ & $14 \%$ & soát \\
\hline Vốn chủ sở hữu & 33.000 & 18.024 & 14.976 & 36.041 & 31.041 & 5.000 & 19.976 \\
\hline Vốn khác của CSH & & & & & & & \\
\hline Quỹ đầu tư phát triển & 36.168 & 19.755 & 16.413 & & & & 16.413 \\
\hline Quỹ dự phòng tài chính & & & & & & & \\
\hline Lợi nhuận chưa phân phố & & & & & & & \\
\hline Cộng & 69.168 & 37.779 & 31.389 & 36.041 & 31.041 & 5.000 & 36.389 \\
\hline
\end{tabular}

(Nguồn: Tác giả tính toán và tổng hợp trên cơ sở báo cáo tài chính của các công ty CP thuộc Tổng công ty Đông Bắc năm 2017).

Bảng 2. Lợi ích cổ đông không kiểm soát trên bảng cân đôi kếtoán hợp nhất năm 2017.

(ĐVT: Triệu đồng)

\begin{tabular}{|l|r|r|r|r|}
\hline \multicolumn{1}{|c|}{ Chỉ tiêu } & Số dư đầu năm & Tăng trong năm & Giảm trong năm & Số cuối kỳ \\
\hline Vốn đầu tư của CSH & 1.204 .735 & 499 & 1.629 & 1.203 .605 \\
\hline Chênh lệch đánh giá tài sản & & 43.974 & & 43.974 \\
\hline Quỹ đầu tư phát triển & 57.891 & 55.867 & 8.423 & 105.334 \\
\hline Nguồn vốn ĐTXDCB & & & & \\
\hline Lợi nhuận chưa phân phối & & & & \\
\hline Lợi ích cổ đông không kiểm soát & 35.841 & 1.048 & 500 & 36.389 \\
\hline \multicolumn{1}{|c|}{ Cộng } & 1.298 .467 & 99.759 & 10.552 & 1.389 .303 \\
\hline
\end{tabular}

(Nguồn: Thuyết minh báo cáo tài chính hợp nhất của Tổng công ty Đông Bắc năm 2017).

Ví dụ: Năm 2019, kế toán tách lợi ích cổ đông không kiểm soát tại thời điểm cuối kỳ theo bút toán:

Nợ Vốn góp của chủ sở hữu: 71.953 triệu đồng

Nợ Quỹ đầu tư phát triển: 11.562 triệu đồng

Nợ Lợi nhuận sau thuế chưa phân phối: 27.737 triệu đồng

Có Lợi ích cổ đông không kiểm soát:

\subsection{3 triệu đồng}

Số liệu trình bày trên bảng cân đối kế toán tài chính hợp nhất của Tổng công ty Đông Bắc giai đoạn 2017-2019 được tính toán qua Bảng 2, Bảng 4 và Bảng 6 (Mục 25 - Vốn chủ sở hữu, trên Thuyết minh Báo cáo tài chính giai đoạn 2017-2019), và số liệu ở các bảng này được tính toán theo công thức (1).

Tuy nhiên theo tác giả, việc tính toán các chỉ tiêu này chỉ được thực hiện đúng trong các năm 2017, 2018 (Bảng 2, 4); còn trong năm 2019 thì Tổng công ty đã chưa thực hiện đúng (Bảng 6).
Trong công thức (1), Lợi ích cổ đông không kiểm soát phát sinh trong kỳ phải được tính bằng Lợi ích cổ đông kiểm soát tăng trong kỳ trừ đi $(-)$ Lợi ích cổ đông kiểm soát giảm trong kỳ. Như vậy thì việc đưa số liệu lên Mục 25 - Vốn chủ sở hữu, trên Thuyết minh Báo cáo tài chính mới đúng được).

Số liệu trình bày trên bảng cân đối kế toán tài chính hợp nhất của Tổng công ty Đông Bắc giai đoạn 2017-2019 được tính toán qua Bảng 2, Bảng 4 và Bảng 6 (Mục 25 - Vốn chủ sở hữu, trên Thuyết minh Báo cáo tài chính giai đoạn 2017-2019), và số liệu ở các bảng này được tính toán theo công thức (1).

Tuy nhiên theo tác giả, việc tính toán các chỉ tiêu này chỉ được thực hiện đúng trong các năm 2017, 2018 (Bảng 2, 4); còn trong năm 2019 thì Tổng công ty đã chưa thực hiện đúng (Bảng 6).

Trong công thức (1), Lợi ích cổ đông không kiểm soát phát sinh trong kỳ phải được tính bằng 
Bảng 3. Bảng tính lợi ích của cổ đông không kiểm soát của các công ty CP thuộc Tổng công ty Đông Bắc năm 2018.

(ĐVT: Triệu đồng)

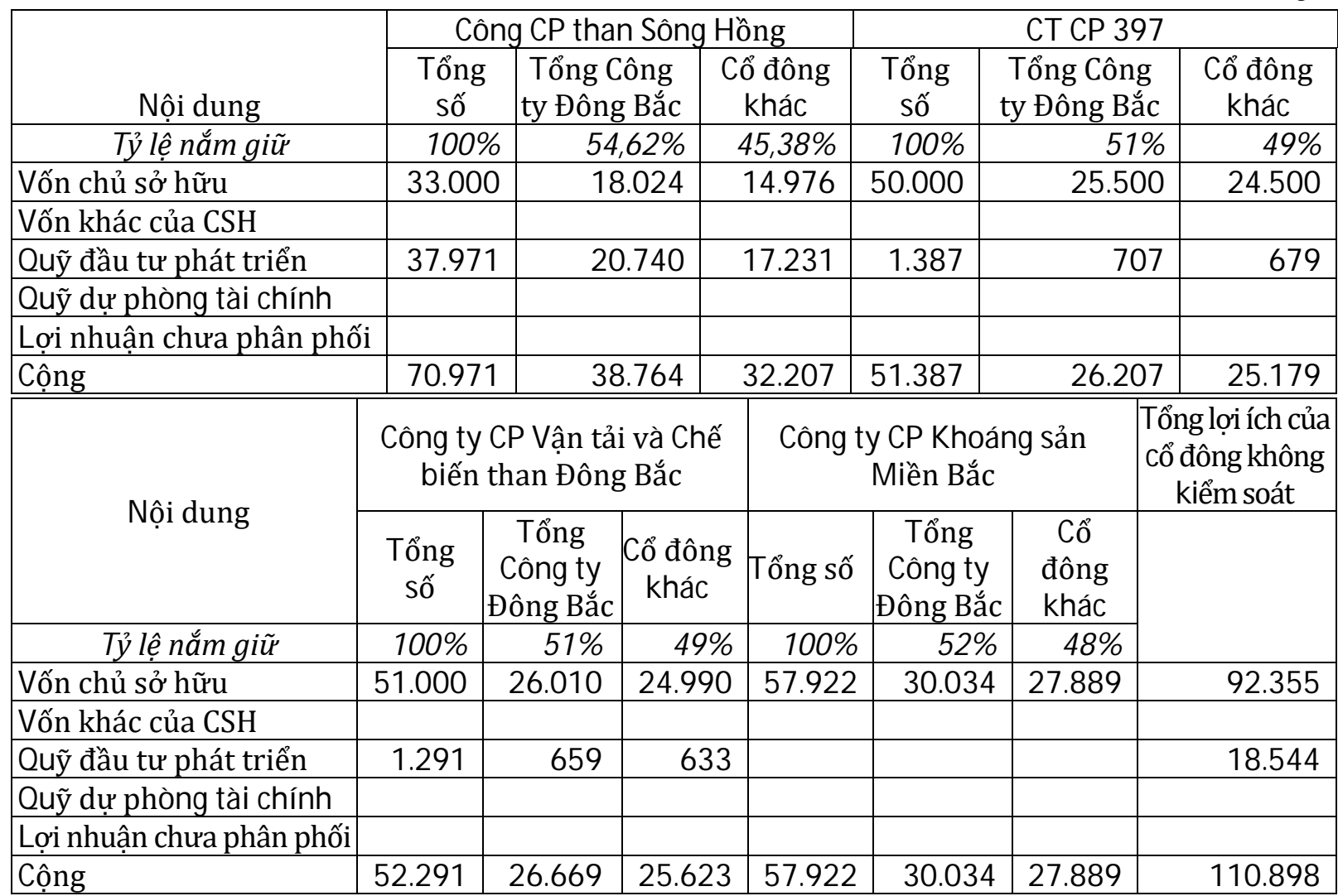

(Nguồn: Tác giả tính toán và tổng hợp trên cơ sở báo cáo tài chính của các công ty CP thuộc Tổng công ty Đông Bắc năm 2018).

Bảng 4. Lọi ích cổ đông không kiểm soát trên bảng cân đôi kếtoán họp nhất năm 2018 .

(ĐVT: Triệu đồng)

\begin{tabular}{|l|r|r|r|r|}
\hline \multicolumn{1}{|c|}{ Chỉ tiêu } & Số dư đầu năm & Tăng trong năm & Giảm trong năm & \multicolumn{1}{c|}{ Số cuối kỳ } \\
\hline Vốn đầu tư của CSH & 1.203 .605 & 87.208 & & 1.290 .814 \\
\hline Chênh lệch đánh giá tài sản & 43.974 & & 43.974 & \\
\hline Quỹ đầu tư phát triển & 105.334 & 38.069 & 90.576 & 52.827 \\
\hline Nguồn vốn ĐTXDCB & & & & \\
\hline Lợi nhuận chưa phân phối & & & & \\
\hline Lợi ích cổ đông không kiểm soát & 36.389 & 74.509 & & 110.898 \\
\hline \multicolumn{1}{|c|}{ Cộng } & 1.389 .303 & 199.786 & 134.550 & 1.454 .539 \\
\hline
\end{tabular}

(Nguồn: Thuyết minh báo cáo tài chính hợp nhất của Tổng công ty Đông Bắc năm 2018).

Lợi ích cổ đông kiểm soát tăng trong kỳ trừ đi (-) Lợi ích cổ đông kiểm soát giảm trong kỳ. Như vậy thì việc đưa số liệu lên Mục 25 - Vốn chủ sở hữu, trên Thuyết minh Báo cáo tài chính mới đúng).

Trong Bảng 6 (số liệu năm 2019), Tổng công ty đã bù trừ số phát sinh tăng và phát sinh giảm để ghi vào Cột Tăng trong năm nên số liệu sẽ không chính xác.
Số đúng phải là: Tăng trong năm = 28.244; Giảm trong năm = 27.889.

Nhưng Công ty lại ghi nhận số liệu Tăng trong năm $=28.244-27.889=355$ và không ghi nhận số phát sinh giảm.

Phần tính toán cụ thể các số liệu trên được tác giả thể hiện trong Bảng 7.

Tổng công ty Đông Bắc không lập sổ kế toán riêng cho khoản mục này, mà chỉ tính toán riêng 
Bảng 5. Bảng tính lọi ích của cổ đông không kiểm soát của các công ty CP thuộc Tổng công ty Đông Bắc năm 2019.

(ĐVT: Triệu đồng)

\begin{tabular}{|c|c|c|c|c|c|c|}
\hline \multirow[b]{2}{*}{ Nội dung } & \multicolumn{3}{|c|}{ Công ty CP 397} & \multicolumn{3}{|c|}{$\begin{array}{l}\text { Công ty CP Vận tải và Chế biến } \\
\text { than Đông Bắc }\end{array}$} \\
\hline & Tổng số & $\begin{array}{c}\text { Tổng } \\
\text { Công ty } \\
\text { Đông Bắc }\end{array}$ & $\begin{array}{c}\text { Cổ } \\
\text { đông } \\
\text { khác }\end{array}$ & Tổng số & $\begin{array}{l}\text { Tổng Công } \\
\text { ty Đông } \\
\text { Bắc }\end{array}$ & $\begin{array}{l}\text { Cổ } \\
\text { đông } \\
\text { khác }\end{array}$ \\
\hline Tỷ lê nắm giũu & $100 \%$ & $51 \%$ & $49 \%$ & $100 \%$ & $51 \%$ & $49 \%$ \\
\hline Vốn chủ sở hữu & 50.000 & 25.500 & 24.500 & 51.000 & 26.010 & 24.990 \\
\hline \multicolumn{7}{|l|}{ Vốn khác của CSH } \\
\hline Quỹ đầu tư phát triển & 1.387 & 707 & 679 & 1.291 & 658 & 633 \\
\hline \multicolumn{7}{|l|}{ Quỹ dự phòng tài chính } \\
\hline Lợi nhuận chưa phân phối & 11.453 & 5.841 & 5.612 & 45.153 & 23.028 & 22.125 \\
\hline Cộng & 62.840 & 32.048 & 30.792 & 97.444 & 59.696 & 47.748 \\
\hline \multirow[b]{2}{*}{ Nội dung } & \multicolumn{4}{|c|}{ Công ty CP than Sông Hồng } & \multirow{3}{*}{\multicolumn{2}{|c|}{$\begin{array}{c}\text { Tổng lợi ích của } \\
\text { cổ đông không } \\
\text { kiểm soát }\end{array}$}} \\
\hline & Tổng số & \multicolumn{2}{|c|}{$\begin{array}{l}\text { Tổng Công ty } \\
\text { Đông Bắc }\end{array}$} & Cổ đông khác & & \\
\hline Tỷ lệ nắm giũu & $100 \%$ & \multicolumn{2}{|c|}{$54,62 \%$} & $45,38 \%$ & & \\
\hline Vốn chủ sở hũu & 49.500 & \multicolumn{2}{|c|}{27.037} & 22.463 & \multicolumn{2}{|r|}{71.953} \\
\hline \multicolumn{7}{|l|}{ Vốn khác của CSH } \\
\hline Quỹ đầu tư phát triển & 22.586 & \multicolumn{2}{|c|}{12.336} & 10.250 & \multicolumn{2}{|r|}{11.562} \\
\hline \multicolumn{7}{|l|}{ Quỹ dự phòng tài chính } \\
\hline Lợi nhuận chưa phân phối & & & & & \multirow{2}{*}{\multicolumn{2}{|c|}{$\begin{array}{r}27.737 \\
111.253\end{array}$}} \\
\hline Cộng & 72.086 & \multicolumn{2}{|c|}{39.373} & 32.713 & & \\
\hline
\end{tabular}

(Nguồn: Tác giả tính toán và tổng hợp trên cơ sở báo cáo tài chính của các công ty CP thuộc Tổng công ty

Đông Bắc năm 2019).

Bảng 6. Lợi ích cổ đông không kiểm soát trên bảng cân đôi kếtoán hợp nhất năm 2019.

(ĐVT: Triệu đồng)

\begin{tabular}{|l|r|r|r|r|}
\hline \multicolumn{1}{|c|}{ Chỉ tiêu } & \multicolumn{1}{c|}{ Số dư đầu năm } & Tăng trong năm & Giảm trong năm & \multicolumn{1}{c|}{ Số cuối kỳ } \\
\hline Vốn đầu tư của CSH & 1.290 .814 & 69.733 & & 1.360 .547 \\
\hline Chênh lệch đánh giá tài sản & & & & \\
\hline Quỹ đầu tư phát triển & 52.827 & 32.282 & 69.734 & 15.376 \\
\hline Nguồn vốn ĐTXDCB & & & & \\
\hline Lợi nhuận chưa phân phối & & 34.756 & & 34.756 \\
\hline Lợi ích cổ đông không kiểm soát & 110.898 & 355 & & 111.253 \\
\hline \multicolumn{1}{|c|}{ Cộng } & 1.454 .539 & 137.126 & 69.734 & 1.521 .933 \\
\hline
\end{tabular}

(Nguồn: Thuyết minh báo cáo tài chính hợp nhất của Tổng công ty Đông Bắc năm 2019).

trên phần mềm Microsoft Excel sau đó đưa lên báo cáo tài chính hợp nhất. Do đó bút toán tách lợi ích cổ đông không kiểm soát tại thời điểm cuối kỳ cũng được dùng để ghi nhận tăng, giảm các chỉ tiêu tương ứng trên báo cáo tài chính hợp nhất chứ không dùng để ghi sổ.

3.2.2. Xác định chỉ tiêu Lọi nhuận sau thuế của cổ đông không kiểm soát trên Báo cáo kêt quả hoạt động kinh doanh hợp nhất của Tổng công ty Đông Bắc
Chỉ tiêu Lợi nhuận sau thuế của cổ đông không kiểm soát trên Báo cáo kết quả kinh doanh hợp nhất của Tổng công ty Đông Bắc được tính bằng tổng lợi nhuận sau thuế của cổ đông không kiểm soát của các công ty CP trong Tổng công ty Đông Bắc.

Trong đó, lợi nhuận sau thuế của công ty cổ phẩn thuộc Tổng công ty Đông Bắc được tính theo công thức (3). 
Bảng 7. Bảng tính toán mức tăng giảm Lợi ích cổ đông không kiểm soát giữa các năm của Tổng công ty Đông Bắc giai đoạn 2017-2019.

\begin{tabular}{|c|c|c|c|c|}
\hline \multirow[b]{2}{*}{ Đơn vị } & \multicolumn{4}{|c|}{ Lợi ích cổ đông không kiểm soát } \\
\hline & $\begin{array}{l}\text { Cuối năm } \\
2016\end{array}$ & $\begin{array}{l}\text { Cuối năm } \\
2017\end{array}$ & $\begin{array}{l}\text { Cuối năm } \\
2018\end{array}$ & $\begin{array}{c}\text { Cuối năm } \\
2019\end{array}$ \\
\hline 1. Công ty CP than Sông Hông & 30.341 & 31.389 & 32.207 & 32.713 \\
\hline Mức tăng, giảm giữa các năm & & $(+) 1.048$ & $(+) 818$ & $(+) 506$ \\
\hline 2. Công ty CP Khoáng sản Miền Bắc & 5.500 & 5.000 & 27.889 & - \\
\hline Mức tăng, giảm giữa các năm & & $(-) 500$ & $(+) 22.889$ & $(-) 27.889$ \\
\hline 3. Công ty CP 397 & - & - & 25.179 & 30.792 \\
\hline Mức tăng, giảm giữa các năm & & 0 & $(+) 25.179$ & $(+) 5.613$ \\
\hline 4. Công ty CP Vận tải và Chế biến than Đông Bắc & - & - & 25.623 & 47.748 \\
\hline Mức tăng, giảm giữa các năm & & 0 & $(+) 25.623$ & $(+) 22.125$ \\
\hline 5. Mức tăng, giảm của Tổng công ty & & $\begin{array}{r}(+) 1.048 \\
(-) 500\end{array}$ & $\begin{array}{r}(+) 74.509 \\
(-) 0\end{array}$ & $\begin{array}{r}(+) 28.244 \\
(-) 27.889\end{array}$ \\
\hline
\end{tabular}

Ghi chú: (+): Tăng; (-): Giảm

(Nguồn: Tác giả tính toán và tổng hợp trên cơ sở báo cáo tài chính của các công ty CP thuộc Tổng công ty Đông Bắc giai đoạn 2017-2019).

Bảng 8. Bảng tính Lợi nhuận sau thuế của cổ đông không kiểm soát của các công ty CP thuộc Tổng công ty Đông Bắc năm 2019.

(ĐVT: Triệu đồng)

\begin{tabular}{|c|c|c|c|c|}
\hline Chỉ tiêu & $\begin{array}{l}\text { Công ty CP than Sông } \\
\text { Hồng (tỷ lệ nắm giữ } \\
54,62 \%: 45,38 \% \text { ) }\end{array}$ & \begin{tabular}{|c|} 
Công ty CP \\
397(tỷ lệ nắm \\
giữ $51 \%: 49 \%$ )
\end{tabular} & $\begin{array}{l}\text { Công ty CP Vận tải và Chế } \\
\text { biến than Đông Bắc (tỷ lệ } \\
\text { nắm giữ } 51 \%: 49 \% \text { ) }\end{array}$ & $\begin{array}{l}\text { Tổng } \\
\text { Cộng }\end{array}$ \\
\hline Lợi nhuận sau thuế TNDN & 5.573 & 11.453 & 45.153 & 62.179 \\
\hline Lợinhuận sau thuếcủaCôngty Me & 3.044 & 5.841 & 23.028 & 31.913 \\
\hline $\begin{array}{l}\text { Lợi nhuận sau thuế của Cổ } \\
\text { đông không kiểm soát }\end{array}$ & 2.529 & 5.612 & 22.125 & 30.266 \\
\hline
\end{tabular}

(Nguồn: Tác giả tính toán và tổng hợp dựa vào Báo cáo tài chính của các công ty $\mathrm{CP}$ thuộc Tổng công ty

Đông Bắc năm 2019)

Lợinhuận sau Tỷlệnắm Lọi nhuận sau thuế của cố $=$ giũ của cổ $\mathrm{x}$ thuế của công ty đông không = đông không $\mathrm{X} \quad \mathrm{CP}$ thuộc Tổng (3) kiểm soát kiểm soát công ty Đông Bắc Việc tính toán chỉ tiêu lợi nhuận sau thuế của Cổ đông không kiểm soát của các công ty CP thuộc Tổng công ty Đông Bắc năm 2019 được thể hiện trên Bảng 8. Các năm 2017, 2018 tính tương tự.

Ví dụ cho năm 2019:

Lợi nhuận sau thuế của

cổ đông không kiểm soát = 45,38\% x 5.573 Sông Hồng năm 2019

= 2.529 (triệu đồng)
Lơi nhuận sau thuế của cổ

đông không kiểm soát của $=49 \%$ x 11.453

công ty CP 397 năm 2019 = 5.612 (triệu đồng)

Lọi nhuộn sau thuếcủa cổ đông không kiểm soát của $=49 \%$ x 45.153 than Đông Bắc năm 2019

$$
=22.125 \text { (triệu đồng) }
$$

Tổng lợi nhuận sau thuế của cổ đông không kiểm soát của Tổng công ty Đông Bắc năm 2019 là: $2.529+5.612+22.125=30.266$ triệu đồng.

Đây cũng là số liệu để điền vào chỉ tiêu thứ 17.2: "Lợi nhuận sau thuế của cổ đông không kiểm soát" trên Báo cáo kết quả hoạt động kinh doanh hợp nhất của Tổng công ty Đông Bắc (Bảng 9). 
Bảng 9. Báo cáo kêt quả hoạt động kinh doanh họp nhất của Tổng Công ty Đông Bắc giai đoạn 20172019.

\begin{tabular}{|c|c|c|c|}
\hline & & & \\
\hline Chỉ tiêu & 2017 & 2018 & 2019 \\
\hline 1. Doanh thu bán hàng và cung cấp dịch vụ & 11.629 .616 & 13.486 .252 & 20.326 .739 \\
\hline 2. Các khoản giảm trừ & 3.980 & 5.632 & 3.191 \\
\hline 3. Doanh thu thuần về bán hàng và cung cấp dịch vụ & 11.625 .635 & 13.480 .619 & 20.323 .548 \\
\hline 4. Giá vốn hàng bán & 9.917 .451 & 11.791 .280 & 18.271 .690 \\
\hline 5. Lợi nhuận gộp về bán hàng và cung cấp dịch vụ & 1.708 .184 & 1.689 .339 & 2.051 .858 \\
\hline 6. Doanh thu hoạt động tài chính & 23.149 & 75.606 & 47.971 \\
\hline 7. Chi phí tài chính & 553.521 & 476.437 & 522.879 \\
\hline Trong đó: Chi phí lãi vay & 492.366 & 446.609 & 460.587 \\
\hline 8. Chi phí bán hàng & 303.170 & 448.566 & 636.618 \\
\hline 9. Chi phí quản lý doanh nghiệp & 555.396 & 525.203 & 550.536 \\
\hline 10. Lợi nhuận thuần từ hoạt động kinh doanh & 319.247 & 314.740 & 389.795 \\
\hline 11. Thu nhập khác & 131.307 & 70.272 & 40.289 \\
\hline 12. Chi phí khác & 129.145 & 50.928 & 75.227 \\
\hline 13. Lợi nhuận khác & 2.162 & 19.344 & (34.938) \\
\hline 14. Tổng lợi nhuận kế toán trước thuế & 321.409 & 334.083 & 354.857 \\
\hline 15. Chi phí thuế thu nhập doanh nghiệp hiện hành & 65.089 & 69.688 & 173.600 \\
\hline 16. Chi phí thuế thu nhập doanh nghiệp hoãn lại & & & \\
\hline 17. Lợi nhuận sau thuế thu nhập doanh nghiệp & 256.319 & 264.396 & 181.257 \\
\hline 17.1 Lợi nhuận sau thuế của Công ty Mẹ & 253.028 & 248.545 & 150.991 \\
\hline 17.2 Lợi nhuận sau thuế của cổ đông không kiểm soát & 3.291 & 15.851 & 30.266 \\
\hline 18. Lãi cơ bản trên cổ phiếu & 2.000 & 2.125 & 4.131 \\
\hline 19. Lãi suy giảm trên cổ phiếu & & & \\
\hline
\end{tabular}

(Nguồn: Báo cáo kết quả hoạt động kinh doanh hợp nhất của Tổng công ty Đông Bắc giai đoạn 2017-2019).

Dựa vào chỉ tiêu lợi nhuận sau thuế của cổ đông không kiểm soát và lợi nhuận sau thuế của công ty Mẹ, Tổng công ty Đông Bắc sẽ có quyết định chia lợi nhuận cho các cổ đông một cách phù hợp.

\section{Kết luận}

Việc lập chỉ tiêu Lợi ích cổ đông không kiểm soát và Lợi nhuận sau thuế của cổ đông không kiểm soát trên Báo cáo tài chính hợp nhất của Tổng công ty Đông Bắc giai đoạn 2017-2019 đượC áp dụng theo Thông tư 202/2014/TT-BTC ngày 22/ 12/ 2014. Kế toán Lợi ích cổ đông không kiểm soát trong Tổng công ty Đông Bắc đã được thực hiện từ ghi nhận ban đầu khi thực hiện thành công việc cổ phần hóa công ty con, đến việc ghi nhận lợi ích cổ đông không kiểm soát từ kết quả hoạt động kinh doanh trong kỳ trên cả Bảng cân đối kế toán hợp nhất và Báo cáo kết quả hoạt động kinh doanh hợp nhất.

Phương pháp lập và trình bày báo cáo tài chính hợp nhất của công ty mẹ và cổ đông không kiểm soát đối với công ty con đã đưa việc lập báo cáo tài chính của Tổng công ty Đông Bắc sát hơn với các tiêu chuẩn trong IFRS10. Tuy nhiên còn có những sai sót nhỏ trong quá trình tính toán mà tác giả đã chỉ ra trong bài báo. Tác giả kiến nghị đối với bộ phận kế toán tại Văn phòng Tổng công ty cần thực hiện cẩn thận hơn nội dung này để thông tin mang đến cho các cổ đông là chính xác.

Các cổ đông không kiểm soát sở hữu một tỷ lệ vốn tương đối lớn trong các công ty $\mathrm{CP}$ thuộc Tổng công ty Đông Bắc. Khi họ đầu tư, họ mong muốn có được những thông tin tài chính minh bạch, kịp thời về lợi ích cổ đông không kiểm soát. Khi đọc báo cáo tài chính hợp nhất, cổ đông không kiểm soát sẽ nắm bắt được họ sở hữu phần vốn chủ sở hữu là bao nhiêu và được chia lợi nhuận sau thuế như thế nào. Điều đó giúp họ đưa ra những quyết định đúng đắn và hiệu quả hơn trong tương lai. Có thể thấy rằng việc áp dụng thông tư 202/ 2014/ TT-BTClập báo cáo tài chính hợp nhất của Tổng công ty Đông Bắc đã giúp nâng cao tính 
công khai, minh bạch trong việc cung cấp thông tin kế toán cho các cổ đông nói chung và các cổ đông không kiểm soát nói riêng.

\section{Những đóng góp của tác giả}

Nguyễn Thị Minh Thu: Khái niệm hóa, phương pháp luận, thu thập và phân tích dữ liệu.

Hoàng Kim Oanh: Phân tích dữ liệu, kiến nghị, viết bản thảo bài báo, đánh giá và chỉnh sửa bài viết.

\section{Tài liệu tham khảo}

Bộ Tài chính, (2014). Thông tư 202/2014/TT-BTC ban hành ngày 22 tháng 12 năm 2014, Hướng dẫn phương pháp lập và trình bày Báo cáo tài chính hợp nhất.

Bộ Tài chính, (2015). 26 chuẩn mực kế toán Việt Nam. Nhà xuất bản Tài chính. Hà Nội, Việt Nam.

International Accounting Standards Board, Standards (IFRSs), (2014). http:/ / www.ifrs.org/ IFRSs/ Pages/ IFRS.aspx.

Nguyễn Văn Ngọc, (2006). Từ điển kinh tế học. Nhà xuất bản Đại học Kinh tế quốc dân. Hà Nội, trang 295.

Tổng công ty Đông Bắc. Tài liệu kế toán các năm 2017, 2018, 2019. 